\title{
Die Hart van Verpleging
}

\author{
'Skenk my 'n liefdevolle hart, o Meester...'
}

\author{
deur Wilma Kotzé
}

D ie mens is n onvermoeibare soeker na sekerheid. na ewewig, na staanplek. Die enigste onveranderbare is die oomblik wat verby is, die verlede. Die toekoms, in sy onbekendheid hou die belofte van gebeurlikheid in — dit stem die mens met verwagting maar ook met onsekerheid omdat ook die onwelkome hom mag inwag. Dit is nogtans die wete van $n$ nuwe daeraad wat in aantog is wat die hoop bring. Daar is altyd die moontlikheid van 'n beter dag. "n beter maand. "n beter jaar wat die hede meer aanvaarbaar maak en die denke. die beplanning meer doelgerig.

Daar word beweer dat die Iwintigste-eeuse mens, meer as ooit tevore in die geskiedenis van die wêreld. in onsekerheid leef. Die politieke ontstuimigheid van die eeu. die onsekere gesagsposisie van die mens teenoor sy tegnologiese skeppinge. die voorspellinge van oorloë, bevolkingsontploffings. hongersnood, verswelging deur besoedeling en ideologieë en talle bedreiginge vanuit die wetenskap hou nie veel gerusstelling in nie. Inderdaad getuig die pogings van die mens van groeiende gerigtheid op die opsporing en uitskakeling van die faktore wat dreig om die ewewig in sy leefwêreld te versteur.

Hierdie mens het ook die gestalte van die sieke. die geneesheer en die verpleegster. Daar word gepraat. beraad gevoer en geskryf oor die leemtes in gesondheidsdienslewering. Literatuur oor die onderwerp het 'n alledaagse geword. Die beskouinge wat dienslewering onderlê kom toenemend onder die vergrootglas — die gesindhede van geneeshere en verpleegsters word ontleed, geweeg en dikwels te lig bevind.

Gesondheidsdienste is die skepping van die mens vir mense. Ook hierdie skepping verraai veel van sy skeppers. Michael Wilson, in sy werk Health is for People spreek die volgende gedagtes uit -

\footnotetext{
"As a picture tells us about the artist who painted it, so a hospital tells us something about the men who make it . .
}

The types of hospitals which we build, faithfully mirror our attitudes to life and death. illness and health: faithfully reveal in mud and wattle or bricks and concrete what man believes about himself. how he understands life, suffering and death; and how he responds to illness, whether by curing, caring, banishing or seeking to probe its causes" (4, p.7)

Watter beeld reflekteer die gesondheidsdiens - die hospitaal, die spreekkamer, die kliniek - na die gemeenskap? Tot watter mate dra gesondheidsdiensleweraars: die gesondheidspan. die individuele geneesheer, verpleegster, paramediese werker by tot die belewing van ongeborgenheid en frustrasie - selfs tot die ontneming van hoop en verwagting - by die mens en die gemeenskap en wie se diens hulle staan?

'n Oop, onbevooroordeelde kyk, veral as ons self in die situasie van pasiënt-word beland, bring hernude waardering vir beweringe wat te dikwels onverskillig en as oordrewe opsygeskuif word. Ons, die lede van die gesondheidspan, staan in diens van die gemeenskap. Dit is immers die behoefte aan gesondheidsdienste by die mens wat tot die ontstaan van die georganiseerde gesondheidsberoepe aanleiding gegee het. en die gehalte dienslewering en die mate van vertroue wat daardeur by die gemeenskap gewek word, wat die voortbestaan van hierdie beroepe waarborg. Ons het bestaansreg ter wille van die bou aan 'n gesonde SuidAfrikaanse volk. Daarom is ons verbind om die gehalte van ons diens voortdurend te bevraagteken ter wille van die verbetering daarvan en bestaan daar geen regverdiging vir onverskilligheid teenoor kritiek nie.

Ons leef in 'n eeu waarin die gees van materialisme onmiskenbaar deel van die Westerse leefwyse is. Die tasbare. sigbare, berekenbare, verklaarbare het daarom veel groter waarde en trefkrag as die ontasbare, die onsigbare, onberekenbare, onverklaarbare. Die 'wonder', die 'misterie', die 'idealistiese' behoort tot die vakgebied van die wysgeer — 'n 'studeerk amer' — of 'leunstoelfilosifie' — en word te dikwels selfs minagtend afgemaak as onprakties en onbereikbaar en daarom nie die moeite werd om te oorweeg nie. 
Die natuurwetenskaplike benadering het derhalwe veel groter aantrekkingskrag as die menswetenskaplike benadering ook in die geneeskunde en die verpleegkunde. Die waarheid van hierdie bewering blyk onontkenbaar uit die leemtes wat steeds in die opleiding van geneeshere en verpleegsters bestaan met betrekking tot die onderrig en inoefening van vaardighede waardeur die student leer om sy of haar persoonlikheid terapeuties te gebruik in die benadering tot die pasiënt en sy naasbestaandes.

Wanneer dienslewering dus evalueer word, bestaan daar die neiging om dit slegs in terme van die ooglopende en bereken- en verklaarbare suksesvolle of onsuksesvolle te oorweeg. Die lewensbeskoulike soos wat dit spreek deur die gesindhede van gesondheidswerkers en uit die interpersoonlike verhoudinge. asook die sukses van terapie in terme van gesindheidsveranderinge, die mate waartoe in pasiënt bereid en in staat was om sy lewensiatroon positief te verander. die mate waartoe betrokkenheid en samewerking van die pasiën en sy naabestaandes verkry is, en of a anvalarding en verwerking van permanente gestremdheid plaasgevind het -. word slegs by uitsondering en in geselekteerde diensleweringsituasies in berekening gebring.

Die beeld wat die gesondheidspan na buite weerspieël skep dit die indruk van 'n onderliggende filosofie dat die genesing van siekte veel belangriker is as die versorging van siek mense? Is dit ook die indruk wat die gemeenskap van die verpleegster het - dat sy teen siektes vaskyk en die mens misloop? Meer en meer skrywers spreek hul besorgdheid hieroor uit - skrywers waarvan die oorgrote meérderheid geneeshere en verpleegsters is.

Die ekspressiewe dimensie van siekeversorging - die dimensie waarin koestering en steungewing die instrumente word om die pyn en lyding meer draaglik en die tegnologie en wetenskap vir die pasiënt meer sinvol te maak - behoort tradisioneel tot die arbeidsterrein van die verpleegster. Haar taak is egter besig om tot sorgwekkende mate te ontplooi om oorwegend die van die verlengde instrumentele arm van die geneesheer te word. In die lig van die eise wat daar in toenemende mate vanuit die wetenskap. die gemeenskap en die geneeskunde aan haar gestel word en aangesien sy dit as primêre verantwoordelikheid het - juis ter wille van die gemeenskap - om in vennootskap aan die sy van die geneesheer en in sy afwesigheid selfs ten opsigte van die volle spektrum van dienslewering te funksioneer, is dit nie "n sonderlinge ontwikkeling nie.

Dit hou egter dringende uitdaging in - naamlik om sorg te dra dat die verpleegster altyd haar taak sal vertolk as oorwegend ekspressief. Hoe groter die uitdaging vir instrumentele taakvervulling - des te groter die eise aan haar om bereid, meer nog voorbereid en bevoegd te wees om -

* die pasiënt in sy nood as mens en as persoon vanuit in eiesoortige leefwêreld met eie betekenisse. eie belange, eie bande raak te sien;

* hom doelbewus in sy besondere situasie van siekwees te gaan leer ken en verstaan;

* hom vanuit die veiligheid van 'n verhouding van begryping, vertroue en simpatieke gesagsleiding tot hernude selfstandigheid en bereidwilligheid tot sinvolle bestaan - met of sonder sy siek te of gestremdheid - te begelei.
Charlote Searle werh latar onomumonde dall dit die ch yper siewe funksie is wat deur die cete heen ian verpleging "n cic karakter verleen. Verarming van hierdie lunksie as die

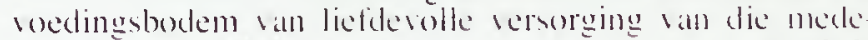

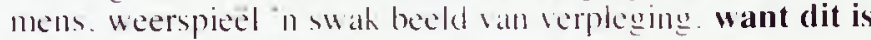
juis en alleenlik hierin

in die blshe lan alam atarding lan die pasient an uniehe persomblihheid en as medemens:

in die verwerkliking van die besoredheid san die verpleegster oor die pasientat: en

in die bereidwillgheid om atan die hand lan steungewing en hulpverlening tot begeleiding van dic parsiön lot sinvolle bestan le kom dat die hart van verpleging klop, en die grootste vreugde in clie anbeid ke.

Daar durf by die verpleegster nooil in gebreh atun deernis watameembatr wees nie. Want dit is Wanneer deemis ver dwy dat die gees van hoele sathlihheid en onbetrohkenheid - die simptome van die material istiese tydsgees - oronem om tussenmenslike verhoudinge ke verarm en van verpleegsorg in blote sake-alangeleentheid te matak

Verpleegkundiges vanuit alle wêrelddele, die gemeenskap aan wie ons onsself diensbaar stel. pleit om "n ontwak ing van medemenslike besorgdheid by verpleegsters. Voor ons lê die. uitdaging van die opgala om in alle opsigte medemens te word. om alle geleenthede aan te gryp on die mens in die dinamiek van sy wêreldbewoning te begryp en om deur hierdie kennis en ons eie individuele moontlikhede, deur voortdurende inoefening, die kuns te bemeester om in alle fasette van pasiëntsorg ons persoonlikhede terapeuties te gebruik.

Die grootste uitdaging in die opleiding van verpleegsters vir die toekoms lê hierin opgesluit.

Die toekoms gaan noodwendig vra vir steeds groter beklemtoning van die instrumentele vaardighede in die verpleegkunde. Indien sy haar plek in die gesondheidspan wil behou sal die verpleegster aan hierdie eise moet voldoen.

Sy sal egter ook haar plek as verpleegster in die werklike betekenis van die woord 'verpleging', naamlik - om te sorg vir. te beskerm. in te staan vir. te koester, liefdevol te behandel. alleen behou as die ewewig bewaar bly tussen die instrumentele en ekspressiewe taakvervulling. Die uitbouing van hierdie ewewig is die sleutel tol die bemeestering van verpleging as kuns - is die sleutel tot daardie kern. die hart. wat die beroep lewend en warm hou en die belydenis van Charlotte Searle tot vervulling bring - verpleging is liefde wat sigbaar gemaak word
1. Kotzé, M.J.: Begeleiding in die verpleegkunde. Universteit van Pretoria. Mei 1978

2. Searle. C.: 'n Suid-Afrikaanse Verplegingscredo. Universiteit van Pretoria. Ohtober 1968 .

3. Searle, C : Verpleegadministrasie - deel I. UNISA. Pretoria. 1975

4. Wilson. W.: He h is for people. Danton. Longman \& Todd Lid. London. 1975. 